\title{
Metodología Para La Detección De Virus De Papa: Pasado, Presente Y Futuro
}

\author{
Luis F. Salazar *
}

\begin{abstract}
RESUMEN
El desarrollo de la metodología usada para detectar los virus en papa es revisada en forma comparativa y en tres etapas definidas: el pasado, el presente y el futuro. La sintomatología causada por los virus en papa fue el primer criterio de detección empleado, se sigue usando en el presente y debido a su rapidez, bajo costo y posibilidad de ser empleada en grandes extensiones de cultivo es improbable que desaparezca en el futuro. El uso de plantas indicadoras ya ha desaparecido como criterio básico de detección de virus debido a su alto costo y demora en producir resultados, principalmente. Las técnicas serológicas usadas hoy en día entre las cuales destaca la técnica de conjugados enzimáticos (ELISA) así como la hibridación de ácidos nucleicos (NASH) serán ampliadas en el futuro para detectar todos los virus del cultivo. Estas técnicas serán mejoradas aún más en sus características de sensibilidad y costo por la utilización de materiales y reactivos más baratos pero igualmente eficientes. La producción de anticuerpos contra los virus tendrá un gran auge con el uso de peptidos virales sintéticos x y posiblemente con mayores estudios en idiotipos.
\end{abstract}

Palabras Claves Adicionales: Serología, ELISA, NASH, idiotipos.

\section{SUMMARY}

\section{DETECTION METHODOLOGIES OF POTATO VIRUSES: PAST, PRESENT AND FUTURE}

The developmental stages of the technology for potato virus detection were revised comparatively taking into consideration future developments. Symptoms caused by potato viruses was the first criterion of virus detection used; it is still in use at present, and due to its simplicity, low cost and possibilities of

* Ph.D., Virólogo Principal. Centro Internacional de la Papa (CIP). Apartado Postal 5969, Lima, Perú. 
being cost applied to large extensions of seed multiplication will probably remain in the future. Indicator plants are no longer used for routine virus detection mainly due to its slowliness to yield results and high costs. Serology, especially the enzymelinked immunoabsorbent assay (ELISA), and the nucleic acid spot hybridization (NASH) are being used at present and their use will be extended in the future. These techniques will be improved even more on their sensitivity and cost effectiveness by the replacement of expensive materials and reagents by others of lower cost but equally efficient. Antisera production will in the future benefit from virus molecular studies for the production of viral synthetic peptides and basic studies on idiotypes.

\section{Additional Index Words: Serology, ELISA, NASH, idiotypes.}

Es bien conocido el efecto de los virus en el cultivo de la papa ya que su control ha tenido siempre prioridad alta. Debido a que las enfermedades virosas solo pueden ser efectivamente controladas por métodos preventivos, los programas de producción de semilla libre, o con bajo nivel de contaminación, resultan imprescindibles. Aún cuando un programa de semillas no solamente tiene como objetivo el control de las enfermedades virosas, éstas representan uno de sus objetivos principales. Un programa eficiente de producción de tubérculo-semilla requiere de una tecnología también eficiente para la detección de enfermedades, especialmente virosas. Para ser eficientes, los métodos de detección de virus requieren conjugar una serie de características como: especificidad (reacción solo con el virus deseado), sensibilidad (mínima cantidad de virus detectado), precisión, simplicidad, rapidez, estabilidad de los reactivos, capacidad de automatización y bajo costo, las mismas que fueron indicadas para los métodos serológicos (5).

A través del tiempo la mejora de los métodos de detección ha sido un objetivo principal en Virología, estos logros en la aplicación práctica de ellos es el motivo del presente artículo.

\section{EL PASADO}

\section{La sintomatología}

La presencia y el efecto dañino de los virus en la papa fue observada 
desde que ésta fue introducida a Europa por Salaman en 1949 (8). Los bajos rendimientos y la presencia de señales evidentes de la infección atribuidos en un principio a la "degeneración" o "cansancio" del material de siembra fue la indicación de la presencia y del efecto de los virus. Estas señales ó síntomas, se convirtieron en un instrumento poderoso en el reconocimiento de las enfermedades virosas. Pronto, sin embargo, se pudo constatar que la sintomatología no era un criterio infalible de detección debido principalmente a la variación de los síntomas, desde la casi inapariencia total (plantas asintomáticas) hasta muerte de las plantas. La variación de los síntomas fue posteriormente atribuida a factores intrínsecos del virus (variantes poco severas), al genotipo del cultivar (generalmente tolerancia genética) y modificadas por factores externos como la temperatura ambiental, humedad del suelo y otros. En países en vías de desarrollo la presencia de otras enfermedades virosas añadió un factor más de variación sintomatológica. Por ejemplo, el enanismo amarillo causado por PLRV en cvs. de $S$. tuberosum spp. andigena o los síntomas causados por virus poco conocidos como tobacco streak (TSV), o tomato spotted wilt (TSWV).

Aún a pesar de esta poca confiabilidad, la sintomatología se continuó utilizando por sus ventajas en rapidez, posibilidad de utilización en programas de poca infraestructura y su factibilidad de ser empleada en plantaciones que involucran gran número de plantas.

La desventaja de la escasez de personal altamente entrenado en el reconocimiento de síntomas virales fue relativa y fácilmente superada por el gran número de oportunidades de capacitación que tuvieron los técnicos para perfeccionarse a través de la ayuda económica de instituciones en países avanzados.

\section{Las plantas indicadoras}

Un gran efecto tuvo el descubrimiento de que algunos virus presentes en plantas infectadas podían infectar otros huéspedes (plantas). Dentro de estos huéspedes se hallaron algunos virus capaces de reaccionar en forma rápida (algunos días) produciendo infección característica con virus determinados. El método comenzó a ser utilizado rutinariamente, sin embargo, la necesidad de ambientes especiales (ejem. invernaderos) para mantener las plantas inoculadas fue una desventaja que impidió su aplicación a gran escala. Para detectar PVY, el método se usó en forma rutinaria inoculando mecánicamente hojas del clon de papa A6 (S. demissum x S. tuberosum var. Aquila) separadas de la planta y mantenidas en cámara húmeda bajo luz artificial.

Aunque las plantas indicadoras preferidas son aquellas que reaccionan con lesiones locales, también pueden ser empleadas aquellas que reaccionan en forma sistémica. Generalmente las plantas indicadoras son usadas para detectar virus transmitidos mecánicamente (por 
inoculación con extractos de la planta a probar), pero hay algunos casos en que se pueden emplear para detectar los virus transmitidos por insectos o por injertos. Algunos huéspedes y los virus que detectan se muestran en la Tabla 1.

Tabla 1. Algunos huéspedes usados como plantas indicadoras de virus de papa.

HUESPED

VIRUS

A. De lesiones locales

A6

Gomphrena globosa

Chenopodium amaranticolor

B. De infección sistémica

$\begin{array}{ll}\text { Nicotiana glutinosa } & \text { PVX, PVY } \\ \text { Nicotiana tabacum } & \text { PVX, PVY } \\ \text { Scopolia sinensis } & \text { PSTVd } \\ \text { Capiscum annuum } & \text { PVX, PAMV } \\ \text { Datura stramonium } & \text { PVX, PLRV (inoc. por } \\ & \text { áfidos) } \\ \text { Lycopcrsicon esculentum } & \text { PSTVd }\end{array}$

${ }^{\text {a }}$ Ocasional o frecuentemente inducen síntomas.

\section{La serología}

Los virus contienen proteína en su estructura por lo que son capaces de inducir la formación de anticuerpos circulantes con preparaciones purificadas. Estos anticuerpos reconocen al virus que les dio origen cuando una solución que los contiene se mezcla con una solución de virus o extracto de plantas infectadas. La reacción es un típico acoplamiento del anticuerpo con el virus. Las primeras pruebas serológicas empleadas fueron de precipitación (en tubos) o microprecipitación (en gotas). Estas pruebas serológicas fueron muy 
utilizadas en países desarrollados hasta 1978-80, principalmente para detectar PVX, PVY, PVS, y PVM. Sin embargo, hasta esa fecha no hubo posibilidad de desarrollar métodos serológicos para detectar PLRV, el virus más importante del cultivo. Los métodos de laboratorio para la detección de PLRV (determinación de callosa por ejemplo) no fueron suficientemente sensitivos.

Las pruebas de difusión en gel nunca fueron adoptadas para uso rutinario debido principalmente al consumo alto de antisueros.

\section{El conocimiento de las enfermedades virosas}

La observación de los daños causados por los virus permitió la identificación de la mayoría de los virus principales del cultivo en países desarrollados. En países en vías de desarrollo los virus principales son los mismos aunque su epidemiología podría ser diferente en algunos casos. Más de 20 virus fueron identificados hasta 1970/72. El problema entonces prácticamente estuvo descrito, su solución encaminada a través de los programas de semilla; sin embargo la eficiencia del control estuvo limitada a los métodos para la detección de los virus existentes y/o su aplicación.

\section{EL PRESENTE}

\section{La sintomatología}

Aún cuando se ha avanzado en el conocimiento de los virus y su sintomatología, la situación no ha cambiado mucho en su uso. Sólo gracias al desarrollo de métodos más precisos y eficientes de detección de virus en niveles básicos de semilla, se han podido reducir las pérdidas de materiales por descarte en multiplicaciones avanzadas.

Este criterio permanece como la medida más práctica y económica aún en el presente, pero, debido a su insensibilidad, solo para uso en grandes extensiones de multiplicación de tubérculo-semilla (ejem. semilla certificada).

\section{Las plantas indicadoras}

Ya casi no existen Programas de Semilla que basen la detección de virus en este procedimiento. En este caso en particular, la rapidez de detección y economía con otros métodos ha hecho obsoleto el uso de plantas indicadoras.

\section{La serología}

Un verdadero repunte tecnológico en la detección de virus ocurrió con la serología. El método de ELISA (enzyme-linked immunosorbent 
assay) descrito por primera vez por Clark y Adams en 1977 (1) fue aplicado en la detección de virus en papa y en países en vías de desarrollo. ELISA fue impulsado por el Centro Internacional de la Papa desde 1978 (9).

ELISA es una prueba serológica basada en la utilización de las propiedades inmunológicas de los anticuerpos y en la amplificación de la reacción por una enzima ligada a ellos. Muchas variantes fueron posibles, pero hasta el momento el método directo de "Double Antibody Sandwich" (DAS-ELISA) es el preferido. Recientemente (1989) se desarrolló otro método sobre papel (nitrocelulosa) llamado "Nitrocellulose Membrane" (NCM-ELISA) (6). Los pasos esenciales en ELISA se describen en la Figura 1.

La alta sensibilidad en la detección de virus por ELISA es el resultado de la amplificación de la reacción debido a la enzima. Esta sensibilidad permitió la detección de PLRV lo cual no era posible con métodos anteriores, incluyendo la prueba de látex sensibilizado (4) en la cual los anticuerpos se fijan a esferas de poliestireno (látex), y de esta manera, la reacción típica de microprecipitación se ve magnificada incrementando su sensibilidad.

El uso de anticuerpos policlonales ha tenido un gran aporte en el desarrollo tecnológico de la serología en la detección de virus. La utilización de anticuerpos monoclonales, preparados como se aprecia en el diagrama de la Figura 2, en ELISA tiene aparentemente un efecto hasta ahora contradictorio en la práctica. Los anticuerpos monoclonales son derivados de la selección y clonamiento individual de las células productoras de un anticuerpo específico para un epitope en el virus. Si la selección es correcta y el epitope es común en todas las variantes del virus, los anticuerpos monoclonales son mucho más sensitivos y estandarizados que los policlonales (mezcla de anticuerpos producidos por varias células). Sin embargo, existe una gran posibilidad de que los anticuerpos monoclonales no encuentren el apitope al cual reconocen en algunas variantes del virus. En este caso la prueba deja de ser confiable.

La posibilidad de producir anticuerpos a partir de otros ya disponibles (idiotipos, Figura 2) es una nueva posibilidad aún en estudio. Los anticuerpos para PLRV fueron producidos exitosamente por Nakashima y Salazar en 1989 (7), sin embargo, en estudios recientes se ha notado la producción de anticuerpos indeseables por este sistema. Se necesita aún mayor investigación en esta tecnología.

DAS-ELISA está bien establecida en muchos países. Mención especial debe hacerse de la empresa Diagnósticos Vegetales en Argentina, la cual ofrece servicios de diagnóstico de virus para los productores de semilla (3). 


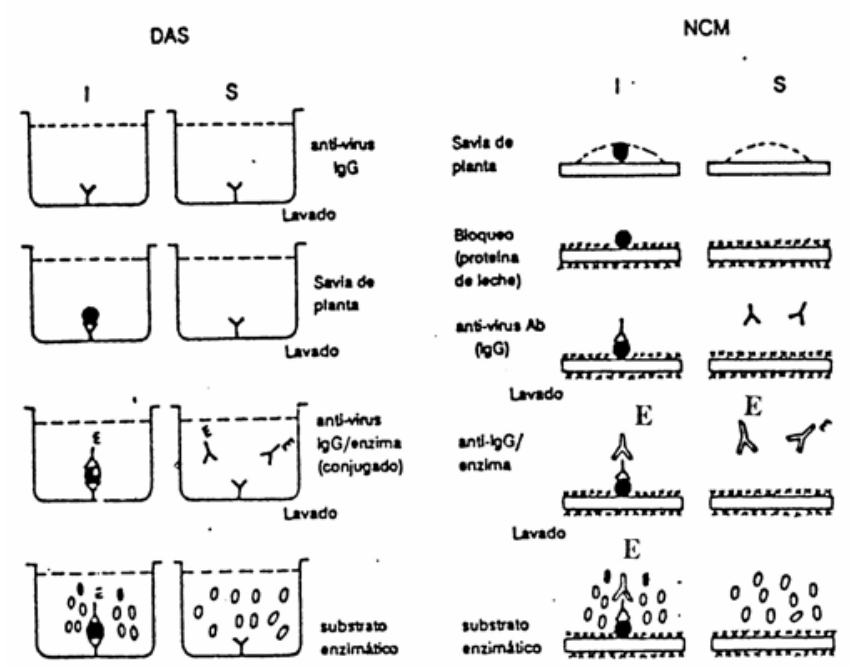

FIGURA 1. Pasos esenciales en ELISA. DAS = double-antibody sandwich; NCM = nitrocellulose nienibrane; $\quad \mathrm{I}=$ savia de planta infectada con virus; $\mathrm{S}=$ Savia de planta sana; $\mathrm{O}=$ substrato degradado (reacción coloreada); $\mathrm{O}=$ substrato no degradado (reacción incolora); $\mathrm{E}=$ Enzima; IgG = inmunoglubina $\mathrm{G}$.
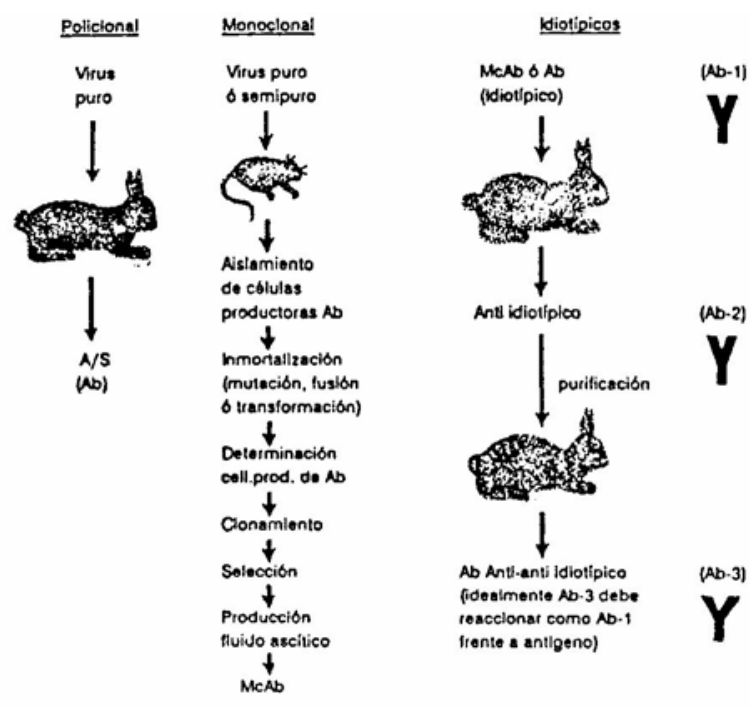

FIGURA 2. Diferentes tipos de anticuerpos para detección de virus. $\mathrm{A} / \mathrm{S}=$ antisuero; $\mathrm{Ab}=$ anticuerpo policlonal; $\mathrm{McAb}=$ anticuerpo monoclonal, Ab-1, Ab-2 y Ab-3 series sucesivas de anticuerpos idiotípicos. 


\section{Hibridación de ácidos nucleicos}

En la década de 1980/90 los avances logrados en el conocimiento molecular de los virus y el desarrollo de la ingeniería genética, han permitido el desarrollo de las técnicas de hibridación de ácidos nucleicos (NASH) como método de detección. La metodología fue desarrollada por primera vez por Diener and Owens en 1981(2) para detectar el viroide del tubérculo ahusado de la papa (PSTVd). Los viroides por no tener proteína en su estructura no pueden ser detectados serológicamente. Un DNA complementario (cDNA) al RNA del viroide puede ser sintetizado, el cual después de ser clonado en un plásmido es multiplicado en una bacteria a voluntad. Este cDNA después de ser marcado con nucleotidos radioactivos o enzimáticos puede ser empleado como una sonda para detectar al viroide.

El procedimiento usado actualmente es muy simple, ya que las muestras depositadas en una membrana de nitrocelulosa son hibridizadas con la sonda de DNA específica, o RNA transcrito de este, y los híbridos que se formen serán detectados por autoradiografía (10) o reacción de la enzima con su substrato (Figura 3). Experimentos con virus han demostrado que esta técnica es igual o más sensitiva que ELISA. La posibilidad de crear sondas altamente específicas o de amplio espectro es una de las ventajas que añadidas hacen de NASH una técnica atractiva en la detección de patógenos.

La comparación de las características de los métodos para la detección de los virus se representa en la Tabla 2.

\section{EI conocimiento de las enfermedades virosas}

Después de 1972 los conocimientos sobre los virus de la papa se profundizó en aquellos ya conocidos. Nuevas razas fueron reconocidas y a través del CIP nuevos virus fueron identificados, tales como: PVT, APMV, APLV, TSV, SALCV, SB-22 (del tipo de AMV), SB-23 (desconocido), y PBRV. Sin embargo, aún quedan varias enfermedades posiblemente de origen viral por identificar, tales como: Deformante en Argentina, amarillamiento de venas en EcuadorColombia y, saq'o en Bolivia.

\section{EL FUTURO}

El futuro parece encaminar hacia el incremento en dos aspectos en la producción de papa que requerirán de la detección de virus. 


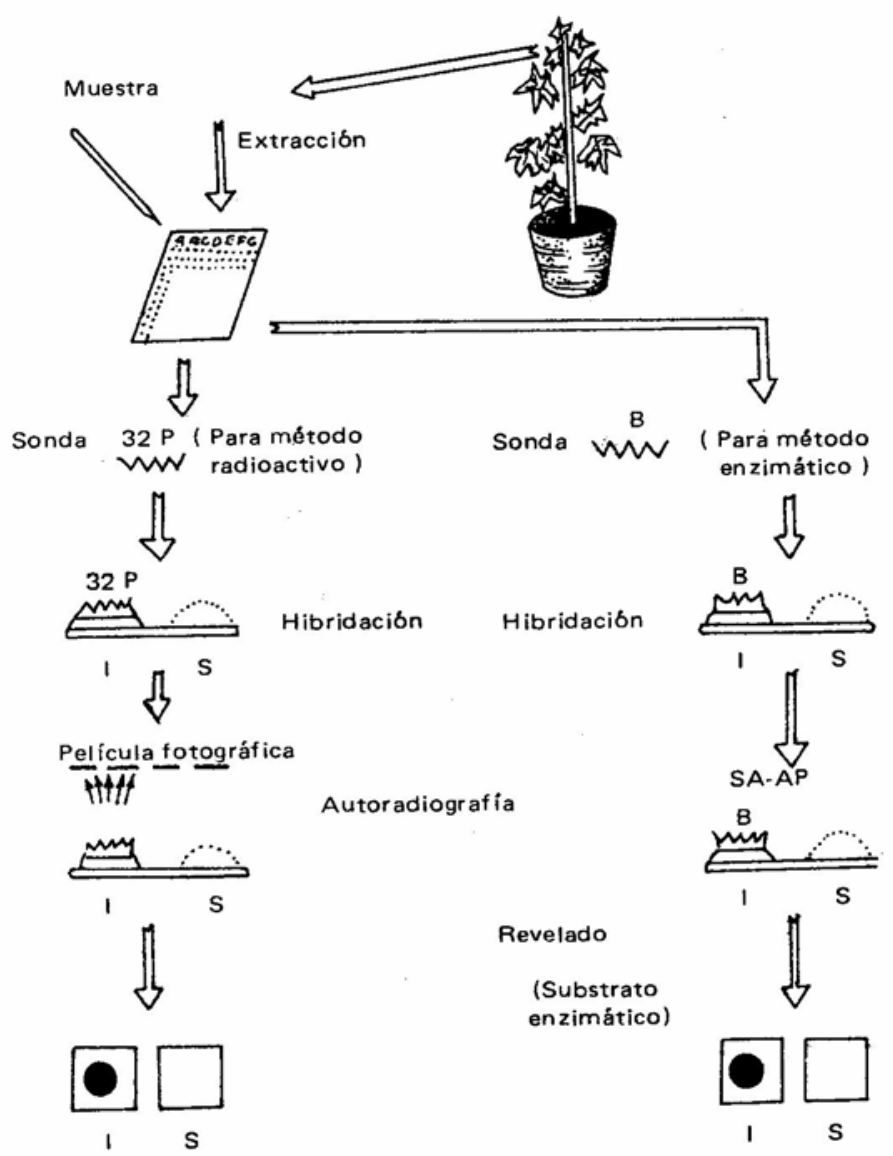

Figura 3. Métodos para la detección de ácidos nucleicos. $\quad \mathbf{B}=$ biotina, $32 p$ = fósforo radioactivo; SA-AP = streptavidina/fosfatasa alcalina; $\mathrm{I}$ = infectado; $\mathrm{S}$ = sano. 
El primero, el incremento de los programas de producción y certificación de tubérculos-semillas de papa, posee suficientes métodos sensitivos para los principales virus del cultivo. El segundo, será el incremento en el movimiento internacional de tubérculos-semillas y materiales genéticos bajo regulaciones cuarentenarias. En este último caso los métodos usados deben ser más precisos. Las técnicas de NASH y ELISA existen pero deben ser adecuadas a esta situación donde patógenos de importancia económica relativamente baja, adquieren un valor cuarentenario.

Tabla 2. Comparación de las características de los diferentes métodos para la detección de virus de papa.

\begin{tabular}{|c|c|c|c|c|c|}
\hline Característica & Sintomatología & $\begin{array}{l}\text { Plantas } \\
\text { indicadoras }\end{array}$ & DAS & NCM & NASH \\
\hline Especificidad & + & ++ & +++ & +++ & +++ \\
\hline $\begin{array}{l}\text { Sensibilidad } \\
\text { Precisión }\end{array}$ & $\begin{array}{l}+ \\
+\end{array}$ & $\begin{array}{c}+++ \\
+\end{array}$ & $\begin{array}{l}+++ \\
+++\end{array}$ & $\begin{array}{l}+++ \\
+++\end{array}$ & $\begin{array}{l}+++ \\
+++\end{array}$ \\
\hline Simplicidad & +++ & + & + & + & + \\
\hline $\begin{array}{l}\text { Rapidez } \\
\text { Estabilidad de } \\
\text { reactivos }\end{array}$ & $\begin{array}{c}+++ \\
\text { n.a }\end{array}$ & $\begin{array}{c}+ \\
\text { na. }\end{array}$ & $\begin{array}{l}++ \\
++\end{array}$ & $\begin{array}{l}++ \\
++\end{array}$ & $\begin{array}{l}+ \\
+\end{array}$ \\
\hline $\begin{array}{l}\text { Capacidad de } \\
\text { automatización }\end{array}$ & 0 & 0 & +++ & ++ & + \\
\hline $\begin{array}{l}\text { Costo } \\
\text { Facilidad de }\end{array}$ & + & +++ & ++ & ++ & ++ \\
\hline $\begin{array}{l}\text { preparación de } \\
\text { reactivos }\end{array}$ & n.a. & n.a. & + & + & + \\
\hline
\end{tabular}

* Los símbolos representan: 0 , imposibilidad total; +, bajo; ++ , media; + + +, alta; n.a., no aplicable.

Es poco probable que a pesar de su sensibilidad NASH pueda totalmente reemplazar a ELISA en los programas de producción de tubérculos-semillas en un futuro cercano. Sin embargo, parece que habrá cambios en ELISA al reemplazar DAS por NCM-ELISA. Además, el mayor énfasis será puesto en reducir el costo de ELISA al utilizar materiales igualmente eficientes pero de mas bajo costo. Por ejemplo, el uso de la enzima penicilinasa en vez de fosfatasa alcalina puede reducir el costo en enzima en un 80 a 90\% (U. Jayashinge, comunicación personal). En NCM-ELISA el reemplazo del papel de nitrocelulosa por otro de uso común podría tener también un efecto grande en la reducción del costo.

Desde el punto de vista científico, en la producción de antisueros varios aspectos tendrán un gran desarrollo en la próxima década. El uso de anticuerpos anti-anti idiotípicos está en estudio. Un resultado positivo en estas investigaciones posibilitaría la producción de 
anticuerpos para los virus principales en todos los países y a un costo relativamente bajo.

La producción de anticuerpos para algunos virus mediante el uso de péptidos virales sintéticos como antígenos es una gran posibilidad gracias al desarrollo de la virología molecular. Estos anticuerpos tienen la posibilidad de ser "construidos" con alta especificidad o con amplio espectro.

El reemplazo de marcadores radioactivos por enzimáticos en NASH ya ha empezado a producir efectos en la difusión de esta técnica, pero al igual que ELISA el costo tendrá que ser reducido. La construcción de sondas de amplio espectro puede hacerse ahora a voluntad y aún existe la posibilidad de combinar la detección, en una sola prueba, de dos o más virus (detección simultánea).

El desarrollo y establecimiento de compañías dedicadas a la prestación de servicios de diagnósticos tendrá un auge grande en el futuro cercano.

\section{REFERENCIAS BIBLIOGRÁFICAS}

1. Clark, M.F.; Adams, A.N. 1977. Characteristics of the microplate method enzyme linked immunoabsorbent assay for the detection of plant viruses. J. Gen. Virol. 34: 475-483.

2. Diener, T.O.; Owens, RA. 1981. Sensitive and rapid diagnosis of potato spindle tuber viroid disease by nucleic acid hybridization. Science 213: 670-672.

3. Escarrá, A.M. 1990. Diagnósticos Vegetales S.R.L. Success in private-public interaction. In: International Potato Center (CIP). Control of virus and virus-like diseases of potato and sweet potato. Report of the 3rd. Plann. Conf., Lima, Perú, 20-22, Nov. 1989. pp. 83-85.

4. Fribourg, C.E.; Nakashima, J. 1984. An improved latex agglutination test for routine detection of potato viruses. Potato Res. 27: 237-249.

5. Gugerli, P. 1990. Advanced immunological techniques for virus detection. In: International Potato Center. (CIP). Control of virus and virus-like diseases of potato and sweet potato. Report of 3rd. Plann. Conf., Lima, Perú, 20-22 Nov. 1989. pp. 29-33. 
6. Lizarraga, C; Fernández-Northcote, E.N. 1989. Detection of potato viruses $\mathrm{X}$ and $\mathrm{Y}$ in sap extracts by a modified indirect enzyme-linked immunoabsorbent assay on nitrocellulose membranes (NCM-ELISA). Plant Disease 73: 11-14.

7. Nakashima, J.; Salazar, L.F. 1989. Reproduction of virus-specific antibodies through idiotyping (?). Fitopatología 24:71-73.

8. Salaman, R.N. 1949. The history and social influence of the potato. Cambridge Univ. Press, London. 685 p.

9. Salazar, L.F. 1979. Aplicación de la técnica serológica con conjugados enzimáticos (ELISA) para diagnosticar virus de la papa. Fitopatología 14: 1-9.

10. Salazar, L.F.; Balbo, I; Owens, RA. 1988. Comparison of four radioactive probes for the diagnosis of potato spindle tuber viroid by nucleic acid spot hybridization. Potato Res. 31: 431-42. 